\title{
Extemporaneous environmental legislation: an analysis of the conflicts underlying Law 3824/1960 on coarse wood removal in Brazilian artificial reservoirs
}

Legislação ambiental extemporânea: uma análise dos conflitos subjacentes à

Lei 3824/1960 sobre a remoção troncos em reservatórios artificiais brasileiros

Lívia Helena Tonella $^{1 *}$ (D), Oscar Barroso Vitorino Junior ${ }^{2}$, Dilermando Pereira Lima Junior ${ }^{3}$, Luiz Carlos Gomes ${ }^{4}$, Fernando Mayer Pelicice 5 and Angelo Antonio Agostinho ${ }^{4}$

1Programa de Pós-graduação em Ecologia de Ambientes Aquáticos Continentais, Universidade Estadual de Maringá - UEM , Av. Colombo 5790, Bloco H-90, CEP 87020-900, Maringá, PR, Brasil

${ }^{2}$ Instituto Natureza do Tocantins-Naturatins, 302 Norte, Alameda 01, Lote 03, Plano Diretor Norte, CEP 77006-336, Palmas, TO, Brasil

${ }^{3}$ Laboratório de Ecologia e Conservação de Ecossistemas Aquáticos, Universidade Federal do Mato Grosso - UFMS, Campus Universitário do Araguaia, Av. Universitária, 3500, CEP 78698-000, Pontal do Araguaia, MT, Brasil

${ }^{4}$ Núcleo de Pesquisas em Limnologia, Ictiologia e Aquicultura, Universidade Estadual de Maringá - UEM, Av. Colombo, 5790, CEP 87020-900, Maringá, PR, Brasil

${ }^{5}$ Núcleo de Estudos Ambientais, Universidade Federal do Tocantins - UFT, Quadra 109 Norte, Avenida NS-15, ALCNO-14 Plano Diretor Norte, CEP 77001-090, Porto Nacional, TO, Brasil *e-mail: livia.tonella@gmail.com

Cite as: Tonella, L.H. et al. Extemporaneous environmental legislation: an analysis of the conflicts underlying Law 3824/1960 on coarse wood removal in Brazilian artificial reservoirs. Acta Limnologica Brasiliensia, 2020, vol. 32, e103

Abstract: This article discusses the purpose and effects of Law 3824/1960, which makes mandatory the removal of vegetation and consequent cleaning of land sites subject to flooding by the construction of artificial reservoirs. The importance of this reflection is to avoid having a law that is considered effective, though if questioned, may prove contrary to the objectives for which it was created. Thus, this article aims to awaken decision makers to the possibility that this law is considered inapplicable to the current reality, according to the social, scientific, legal and environmental advances achieved in recent years. As a specific objective, based on the findings obtained, we aim to stimulate authorities to act in favor of the elaboration of a law that will meet these advances.

Keywords: vegetation suppression; dams; law; deviation from the legal system.

Resumo: Este artigo discute a finalidade e os efeitos da Lei 3824/1960, que torna obrigatória a remoção da vegetação e consequente limpeza dos terrenos sujeitos a inundação pela construção de reservatórios artificiais. A importância dessa reflexão é evitar que uma lei considerada efetiva, ainda que questionada, possa ser contrária aos objetivos para os quais foi criada. Assim, este artigo visa despertar os tomadores de decisão para a possibilidade de essa lei ser considerada inaplicável à realidade atual, de acordo com os avanços sociais, científicos, jurídicos e ambientais alcançados nos últimos anos. Como objetivo específico, com base nos resultados obtidos, pretendemos estimular as autoridades a agirem em favor da elaboração de uma lei que atenda a esses avanços.

Palavras-chave: supressão de vegetação; barragens; direito; desvio do sistema legal. 


\section{Introduction}

Brazil has approximately 200,000 laws currently in force, and approximately 18 new laws are created daily (Amaral et al., 2017). However, some of them may not be fulfilling a relevant role for society, considering that many are unconstitutional, while others are old and were formulated in other temporal contexts and, therefore, have been applied for distinct purposes other than those initially intended. This phenomenon is the case for Law 3824, passed on November 231960 (Brasil, 1960), under President Juscelino Kubitschek, popularly known as "Lei da Destoca" (Law of coarse wood removal). This law makes it mandatory to remove vegetation and clean up areas to be flooded by reservoirs or other artificial lakes, with the purpose of facilitating fishing with nets. However, currently this law has been applied to remove all flooded vegetation for supposedly protect water quality in reservoirs (anoxia and greenhouse gas emissions).

The motivation to perform the total removal of vegetation to prevent the establishment of anoxic water condition and emission of greenhouse gases, mainly due to the decomposition of organic matter that is flooded (Almeida et al., 2019), coming into conflict with knowledge generated since the 1960s (Agostinho et al., 2007). The maintenance of submerged trunks in reservoirs, in addition to not being the main source of oxygen consumption or atmospheric emissions, due to the low decay rate, (Agostinho et al., 2007), is a management strategy linked to the preservation of areas of refuge for juveniles or small species against predation and substrates for periphyton that increases the biological productivity of reservoirs (Góis et al., 2015).

It is known that freshwater ecosystems are highly degraded as a result of multiple human actions (Dudgeon et al., 2006; Vilmi et al., 2017; Reid et al., 2019). In the last decade, in addition to threats linked to different human activities (dams, agriculture, mining, aquaculture, fishing and watershed transposition), neotropical freshwater ecosystems have been increasingly affected by weakened legislation, expanding the limits of economic activities and misguided mitigation strategies (Pelicice et al., 2017). In simplified artificial environments, such as reservoirs, the presence of varied habitats is a determinant for the maintenance of biodiversity (Ploskey, 1985). In this sense, the total removal of vegetation before the filling of reservoirs, seen as a determination of the "Lei da Destoca", decreases the availability of habitats and has a negative impact on the biota and the productivity of the new environment. This article discusses the contradictions in this law, considering its original motivation and the scientific, social, legal and social advances in the last 50 years, in addition to providing elements for an eventual update of the abovementioned law.

\section{Law 3824/1960 on Coarse Wood Removal ("Lei da Destoca")}

Law 3824/1960 (Brasil, 1960) was created by Federal Deputy Joaquim Nunes Coutinho Cavalcanti by the bill (PL 1352/1951) (Figure 1) with the following justification:

The purpose of the bill is to avoid the loss of large areas of land that, when flooded, become useless for fish farming. Consequently, there is no possibility of rational fishing, from a commercial point of view, if this circumstance is not met. This is what happened in Santo Amaro, State of São Paulo, where immense flooded areas did

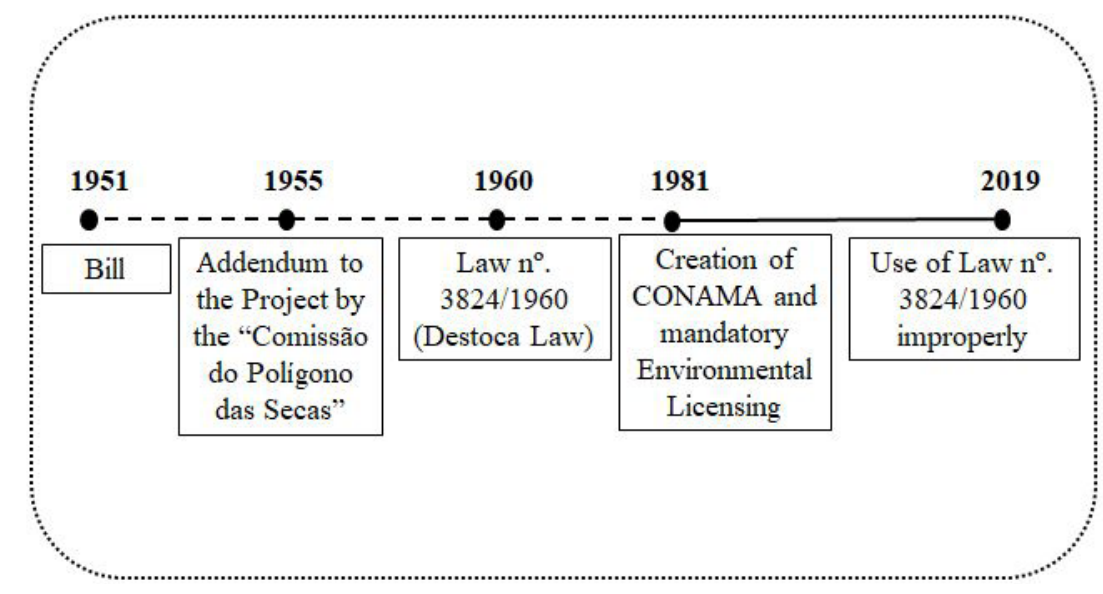

Figure 1. Timeline of Law no. 3824/1960 (Brasil, 1960). 
not have their vegetation removed and no land cleaning, becoming useless for fishing with nets.

It is noteworthy that the initial proposal of the law did not address the possibility of areas not subject to vegetation removal, as seen:

Art. 1 The removal and cleaning of areas to be flooded by reservoirs or other artificial lakes is mandatory.

Art. 2 This Law will enter into force on the date of its publication, revoking any provisions to the contrary.

The need to remove all vegetation in flooded areas appeared first during the evaluation of the "Comissão dos Transporte, Comunicação and Obras Públicas and on Comissão Especial do Polígono da Secas" of the Brazilian National Congress. The latter carried out a consultation in 1952 with the "Comissão Técnica de Piscicultura of DNOCS (Departamento Nacional de Obras Contra as Secas)", which pronounced itself in favor of the bill with the following allegation: (Brasil, 1955)

[...] with regard to the dams under construction, it is important to consider that, before the first filling, tree trunks and larger shrubs should be carefully eliminated, so that the fishing nets can then work without the inconveniences that are currently seen in Lima Campos and other reservoirs.

The first mention of the possibility of leaving areas with vegetation is then presented in the opinion of the "Comissão do Polígono das Secas", dated June 1955 (Figure 1); they recommended that (Brasil, 1955)

[...] the vegetation whose canopy does not exceed the lowest quota of the gallery be preserved, with which it will be assured greater protection to the ichthyofauna to depletions and greater guarantee to the so-called "intangible reserve for the fish farming".

In this amendment, the bill is most similar to its final form, as follows: ((Brasil, 1955, pp. 14-15)

Art. 1 - The removal and consequent clearing of the hydraulic basins of dams, reservoirs or artificial lakes, built by the Union, by the States, by the Municipalities or by private companies that enjoy concessions or any favors granted by the Public Power, is mandatory.

Sole Paragraph - Rural owners will be equally obliged to proceed with these operations when their dams or lakes are built with financial aid or in cooperation with the Public Power.

Art. 2 - Areas with vegetation that, at the discretion of technicians (our emphasis), are considered necessary for the protection of the ichthyofauna, and the reserves essential to guarantee fish farming will be left in the reservoir.

Art. 3 - This law will enter into force on the date of its publication, revoked the provisions to the contrary.

Thus, it is clear that this law was created with the objective of facilitating fishing in reservoirs or other artificial lakes. The central issue was the maintenance of economic activates (fishing) in areas that would otherwise be of value to agricultural activities.

\section{Law Enforcement in Environmental Licensing}

The negative experience with the deterioration in water quality and fish mortality in Amazonian reservoirs, especially in the Balbina Reservoir, has led to the emergence of the "Lei da Destoca" as a solution to fish mortality problems in new reservoirs. Due to the difficulty of interpreting the law in relation to the criteria for establishing areas not requiring vegetation removal, the requirement of total vegetation suppression has been maintained until nowadays.

However, with the obligation established in the Federal Constitution of 1988 (Brasil, 1988) and by the National Council of the Environment (Brasil, 1997) resolutions, licensing and environmental impact studies began to be required for potentially impactful projects since the early 1990s.

Article 8 I of CONAMA Resolution 237/97 (Brasil, 1997) states that prior licensing is granted in the preliminary phase of planning the activity or enterprise, which approves its location and conception, attests to its environmental feasibility and establishes the basic requirements and conditions to be met in the following phases of implementation. Among the demands for the prior license are those contained in the terms of reference related to the suppression of vegetation. The quantification of the vegetation to be suppressed in the inundated area is required, considering the parameters of water quality, areas critical to the ichthyofauna, scenic beauty, erodibility and slope. Since then, water quality has been subject to mathematical modeling, 
with conditions that define the amount of biomass to be removed and that simulate future scenarios with different intensities of vegetation removal and reservoir filling speeds.

\section{Inconsistency of the "Lei da Destoca"}

As discussed above, in the initial draft of Law 3824/1960, removal of vegetation was not featured with the justification for preventing water anoxia in reservoirs, but to facilitate the operation of fishing gears, especially trawlnet. However, the present law is being used in this sense by environmental control agencies in some states of the Federation, such as the cases of the Mato Grosso State. Thus, having as justification the maintenance of water quality parameters, the total removal of vegetation has been demanded, therefore going far beyond the objectives and ignoring the measures to protect fisheries.

The requirement to remove vegetation from reservoirs has persisted for a long time, as is well characterized in the Rosana Reservoir, on the Paranapanema River, and in the Peixe Angical Reservoir, on the Tocantins River. It should be noted that the motivation for carrying out the removal of coarse woods conflicts with the need to protect aquatic biodiversity. The scientific literature shows that areas with flooded trunks generate positive effects on fish density, recruitment, reproduction and refuge (Ploskey, 1985; Góis et al., 2012) and, consequently, on fish production. It is worth noting that fishers prefer to be exposed to the risk of having their fishing material damaged by submerged trunks, rather than fishing in places with lower fish density (Davis \& Hughes, 1971; Agostinho et al., 2007).

\section{Final Remarks}

We consider that the motivation for the Law 3824/1960, which determined log removal before impoundment, was based on allowing the operation of fishing gears. This situation is still legally in force since the law was approved. Still, it is contrary to what the current literature advocates and with what is intended with the maintenance of submerged trunks in reservoirs, i.e., to ensure more favorable conditions of food availability and to provide protection against predation, including those linked to an exacerbated exploitation by fishing, once a reservoir is formed. We understand the consequences of flooding an excessive amount of vegetation, especially the most labile, on hypoxia and undesirable emissions of greenhouse gases $\left(\mathrm{CO}_{2}\right.$ and methane). However, modern mathematical models make it possible to estimate with sufficient precision the appropriate amount of plant material to be removed, and the adverse effects can be avoided. It is, therefore, urgent that a new law, considering these scenarios, regulate future vegetation suppression events for impoundments. Thus, a revision of the legal provisions is the starting point for the formation of a coherent legal infrastructure integrated to the scientific sectors and should be initiated as soon as possible.

\section{Acknowledgements}

We acknowledge the Brazilian Council of Research (CNPq and CAPES) for providing grants for L. H. Tonella, Dilermando-JR, PL, Gomes, LC, Pelicice, FM and A. A. Agostinho.

\section{References}

AGOSTINHO, A.A., GOMES, L.C. and PELICICE, F.M. Ecologia e manejo de recursos pesqueiros em reservatórios do Brasil. Maringá: Eduem, 2007.

ALMEIDA, R.M., SHI, Q., GOMES-SELMAN, J.M., WU, X., XUE, Y., ANGARITA, H., BARROS, N., FORSBERG, B.R., GARCÍA-VILLACORTA, R., HAMILTON, S.K., MELACK, J.M., MONTOYA, M., PEREZ, G., SETHI, S.A., GOMES, C.P. and FLECKER, A.S. Reducing greenhouse gas emissions of Amazon hydropower with strategic dam planning. Nature Communications, 2019, 10(1), 1-9. http://dx.doi.org/10.1038/s41467-019-12179-5. PMid:31537792.

AMARAL, G.L., OLENIKE, J.E., AMARAL, L.M.F., YAZBEK, C.L. Quantidade de normas editadas no Brasil: 28 anos da Constituição Federal de 1988. Curitiba: Instituto Brasileiro de Tributação. 2017.

BRASIL. Câmara dos Deputados. Dossie Lei de Destoca - PL 1352/1951 - Lei 3824/1960. Rio de Janeiro, 1955. Acervo pessoal.

BRASIL. Lei No. 3.824, de 23 de Novembro de 1960 [online]. Diário Oficial da União [da] República Federativa do Brasil, Poder Executivo, Brasília, DF, 1960 [viewed 2 Feb. 2019]. Available from: http:// www.planalto.gov.br/ccivil_03/leis/1950-1969/ L3824.htm

BRASIL. Constituição da República Federativa do Brasil: promulgada em 5 de outubro de 1988. [online]. Diário Oficial da União [da] República Federativa do Brasil, Brasília, DF, 1988 [viewed 4 Feb. 2019]. Available from: http://www.planalto.gov.br/ ccivil_03/constituicao/constituicao.htm

BRASIL. Conselho Nacional do Meio Ambiente CONAMA. RESOLUÇÃO No 237 , DE 19 DE dezembro DE 1997 [online].Diário Oficial da Uniāo [da] República Federativa do Brasil, Poder Executivo, Brasília, DF, 19 dez. 1997 [viewed 4 Feb. 2019]. 
Available from: http://www2.mma.gov.br/port/ conama/res/res97/res23797.html

DAVIS, J.T. and HUGHES, J.S. Effects of standing timber on fish populations and fisherman success in Bussey Lake, Louisiana. In: G.E. HALL, eds. Reservoir fisheries and limnology. Washington: American Fisheries Society, 1971, pp. 255-264.

DUDGEON, D., ARTHINGTON, A.H., GESSNER, M.O., KAWABATA, Z.-I., KNOWLER, D.J., LÉVÊQUE, C., NAIMAN, R.J., PRIEURRICHARD, A.-H., SOTO, D., STIASSNY, M.L.J. and SULLIVAN, C.A. Freshwater biodiversity: importance, threats, status and conservation challenges. Biological Reviews of the Cambridge Philosophical Society, 2006, 81(2), 163-182. http://dx.doi.org/10.1017/S1464793105006950. PMid:16336747.

GOIS, K.S., ANTONIO, R.R., GOMES, L.C., PELICICE, F.M. and AGOSTINHO, A.A. The role of submerged trees in structuring fish assemblages in reservoirs: two case studies in South America. Hydrobiologia, 2012, 685(1), 109-119. http://dx.doi. org/10.1007/s10750-011-0843-9.

GOIS, K.S., PELICICE, F.M., GOMES, L.C. and Agostinho, A.A. Invasion of an Amazonian cichlid in the Upper Paraná River: facilitation by dams and decline of a phylogenetically related species. Hydrobiologia, 2015, 746, 401-413.

PELICICE, F.M., AZEVEDO-SANTOS, V.M., VITULE, J.R.S., ORSI, M.L., LIMA JUNIOR, D.P.,
MAGALHÁES, A.L.B., POMPEU, P.S., PETRERE JUNIOR, M. and AGOSTINHO, A.A. Neotropical freshwater fishes imperiled by unsustainable policies. Fish and Fisheries, 2017, 18(6), 1119-1133. http:// dx.doi.org/10.1111/faf.12228.

PLOSKEY, G.R. Impacts of terrestrial vegetation and preimpoundment clearing on reservoir ecology and fisheries in USA and Canada. FAO Fisheries Technical Paper, 1985, 258, 1-35.

REID, A.J., CARLSON, A.K., CREED, I.F., ELIASON, E.J., GELL, P.A., JOHNSON, P.T.J., KIDD, K.A., MACCORMACK, T.J., OLDEN, J.D., ORMEROD, S.J., SMOL, J.P., TAYLOR, W.W., TOCKNER, K., VERMAIRE, J.C., DUDGEON, D. and COOKE, S.J. Emerging threats and persistent conservation challenges for freshwater biodiversity. Biological Reviews of the Cambridge Philosophical Society, 2019, 94(3), 849-873. http://dx.doi. org/10.1111/brv.12480. PMid:30467930.

VILMI, A., ALAHUHTA, J., HJORT, J., KÄRNÄ, O.M., LEINONEN, K., ROCHA, M.P., TOLONEN, K.E., TOLONEN, K.T. and HEINO, J. Geography of global change and species richness in the North. Environmental Reviews, 2017, 25(2), 184-192. http:// dx.doi.org/10.1139/er-2016-0085.

Received: 09 October 2019 Accepted: 07 April 2020

Associate Editor: Rafael Marques Almeida. 